\title{
ANALISIS KENDALA PROSES PEMBELAJARAN DARING DI KELAS 2B SDN PENGADEGAN 07 JAKARTA TAHUN AJARAN 2021/2022 PADA TEMA TUGASKU SEHARI-HARI
}

\author{
Siti Syarah', Febrianti Yuli Satriyani² \\ ${ }^{1}$ Universitas Trilogi \\ Email: Syarahzrk@gmail.com \\ ${ }^{2}$ Universitas Trilogi \\ Email: Febriantiyuli@trilogi.ac.id
}

\begin{abstract}
Abstrak
Latar belakang penelitian ini adalah peneliti ingin mengetahui dan mendeskripsikan lebih lanjut megenai kendala proses pembelajaran daring dikelas 2B SDN Pengadegan 07 Jakarta Tahun Ajaran 2020/2021 Pada Tema Tugasku Sehari-Hari dengan jenis penelitian Kualitatif Deskriptif. Penelitian ini bertujuan untuk menjelaskan pelaksanaan proses pembelajaran, menjelaskan kendala yang dialami oleh guru dan siswa dan upaya yang dilakukan guru dalam mengatasi kendala pada proses pembelajaran daring dikelas 2B SDN Pengadegan 07 Jakarta Tahun Ajaran 2020/2021 Pada Tema Tugasku Sehari-Hari. Hasil penelitian menunjukan bahwa proses pembelajaran daring hanya menggunakan whatsapp group saja tanpa adanya zoom, classroom dan aplikasi penunjang lainnya. Pada proses pembelajaran, tentunya ada kendala yang dihadapi baik dari guru maupun siswa, seperti kendala handphone, kuota, materi pembelajaran, orang tua yang tidak dapat mendampingi pembelajaran dikarenakan bekerja, pengumpulan tugas yang telat, siswa yang kurang memahami materi. Tetapi, guru memiliki upaya dalam mengatasi kendala tersebut, seperti guru tidak memberikan batas waktu pengumpulan tugas, selalu bekerja sama dengan orang tua pada proses pembelajaran, memberikan semangat kepada siswa dalam bentuk video dan gambar.
\end{abstract}

Kata kunci: Kendala Pembelajaran, Pembelajaran Daring, Tematik

\begin{abstract}
This background is researcher who wants to know and further describe the obstacle of online learning process in class 2B SDN Pengadegan 07 Jakarta Year 2020/2021 with a type of Descriptive Qualitative research. This research aims to explain the implementation of experienced by teachers and student, and efforts teachers take in overcoming obstacles in the online learning process in the class of $2 B S D N$ Pengadegan 07 Jakarta Year 2020/2021. Result of research suggest that the process online learning uses only whatsapp group withput zoom, classroom and other support applications. In the learning process, surely there are obstacles faced by both teachers and students, such as mobile phone constraints, quota, learning materials, parents who cannot accompany the learning due to work, late task collection, students who lack understanding of the material. However, teachers have an effort in overcoming the obstacle, such as teachers fo not give the task collection deadline, always working with parents on the online learning, giving students a spirit in video and image.
\end{abstract}

Keywords: Learning Obstacles, Online Learning, Tematic 
Pendahuluan

Menteri

Pendidikan

dan

Kebudayaan,

Nadiem

Makarim

menerbitkan Surat Edaran Nomor 4

Tahun 2020 tentang pelaksanaan kebijakan pendidikan dalam masa darurat penyebaran virus Corona disease (COVID-19) yang menyatakan dan menetapkan pembelajaran tatap muka pada semester genap tahun ajaran 2020/2021 dan tahun akademik 2020/2021 berdasarkan panduan sebagaimana tercantum dalam lampiran yang merupakan bagian tidak terpisahkan dari keputusan bersama ini, proses pembelajaran yang awalnya dilakukan secara langsung (offline) berubah menjadi secara daring (online) dikecualikan bagi pesantren dan pendidikan keagamaan lainnya (Kemendikbud, 2020).

Berdasarkan hasil studi pendahuluan yang peneliti lakukan pada guru kelas 2B SDN Pengadegan 07 Jakarta pada Bulan September 2021 melalui metode wawancara dan observasi terkait pembelajaran didapatkan bahwa dalam kegiatan pembelajaran guru mengalami kendala yaitu guru tidak memahami penggunaan fitur whatsapp karena usia yang sudah lanjut sehingga kegiatan pembelajaran menjadi kurang menarik, orang tua siswa yang bekerja sehingga tidak bisa mendampingi siswa untuk belajar menggunakan aplikasi zoom menyebabkan kegiatan pembelajaran hanya menggunakan aplikasi whatsapp group dan pengumpulan tugas siswa menjadi terlambat sampai dengan malam hari, kendala lainnya yaitu waktu dalam kegiatan pembelajaran sangat singkat sehingga guru menjadi tidak leluasa dalam memberikan penjelasan materi pembelajaran.

Pembelajaran secara daring merupakan cara baru dalam proses belajar mengajar yang memanfaatkan perangkat elektronik khususnya internet dalam penyampaian belajar. Pembelajaran daring, sepenuhnya bergantung pada akses jaringan internet. Pembelajaran daring merupakan bentuk penyampaian pembelajaran konvensional yang dituangkan pada format digital melalui internet. Pembelajaran daring, dianggap menjadi satu-satunya media penyampaian materi antara guru dan siswa, dalam masa darurat pandemi (Imania, 2019).

\section{Metode Penelitian}

Penelitian ini merupakan penelitian analisis deskriptif kualitatif. Secara harfiah, penelitian kualitatif adalah jenis penelitian yang hasil temuannya tidak diperoleh melalui suatu prosedur yang melibatkan perhitungan statistik atau 
bentuk cara lainnya yang menggunakan ukuran angka. Kualitatif adalah segala sesuatu yang berkaitan dengan aspek kualitas, nilai atau makna yang terdapat dalam suatu fakta, kualitas, nilai atau makna yang hanya dapat diungkapkan melalui bahasa atau kata-kata (Rezky, 2020).

Lokasi penelitian adalah tempat yang dipilih oleh peneliti untuk melaksanakan penelitian untuk memperoleh data yang berkaitan dengan permasalahan penelitian. Tempat yang akan dijadikan lokasi penelitian yaitu SDN Pengadegan 07 Jakarta Jl. Pengadegan Barat VIII No. 13 RT.7/RW.4, Pengadegan, Kec. Pancoran. Kota Jakarta Selatan., 12770. Dengan goggle maps https://bit.ly/3Cc77f0 Subjek penelitian deskripstif kualitatif ini adalah siswa SDN Pengadegan 07 dengan jumlah siswa dalam satu kelas 30 orang.

\section{Hasil dan Pembahasan}

Penelitian ini membahas tentang analisis kendala proses pembelajaran daring di kelas $2 \mathrm{~B}$, kendala yang dialami guru dan siswa kelas $2 \mathrm{~B}$ dan upaya guru dalam mengatasi kendala pada pembelajaran daring. Hasil dari penelitian ini sebagai berikut :
1. Pelaksanaan Proses Pembelajaran Daring di Kelas 2B SDN Pengadegan 07 Jakarta

Berdasarkan hasil observasi yang dilakukan oleh peneliti terhadap seluruh siswa kelas 2B SDN Pengadegan 07 Jakarta diperoleh data mengenai proses pembelajaran daring meliputi kehadiran siswa selama kegiatan pembelajaran, keaktifan siswa dalam proses pembelajaran, interaksi dua arah yang terjadi antara guru dan siswa, dan hasil belajar siswa selama pembelajaran daring. Pada sub bab ini dipaparkan mengenai hasil penelitian yang sudah dilakukan peneliti dilapangan. Pada tanggal 29 September 2021 peneliti mendapatkan hasil penelitian yang meliputi hasil observasi dan wawancara mengenai pelaksanaan proses pembelajaran secara daring siswa kelas 2B SDN Pengadegan 07 Jakarta tahun ajaran 2021/2022 pada tema tugasku sehari-hari. Sebelum melaksanakan proses pembelajaran, setiap guru wajib 
membuat RPP terlebih dahulu untuk menggunakan aplikasi zoom meeting panduan PJJ. Setelah guru membuat tetapi hal tersebut dinilai kurang efektif RPP, maka akan berlangsung proses dikarenakan ada beberapa kendala yang pembelajaran. Proses pembelajaran yang dihadapi. Hal ini ditunjang dengan hasil dilakukan selama penelitian hanya wawancara dan hasil observasi sebagai menggunakan aplikasi whatsapp group, berikut:

sebelumnya proses pembelajaran
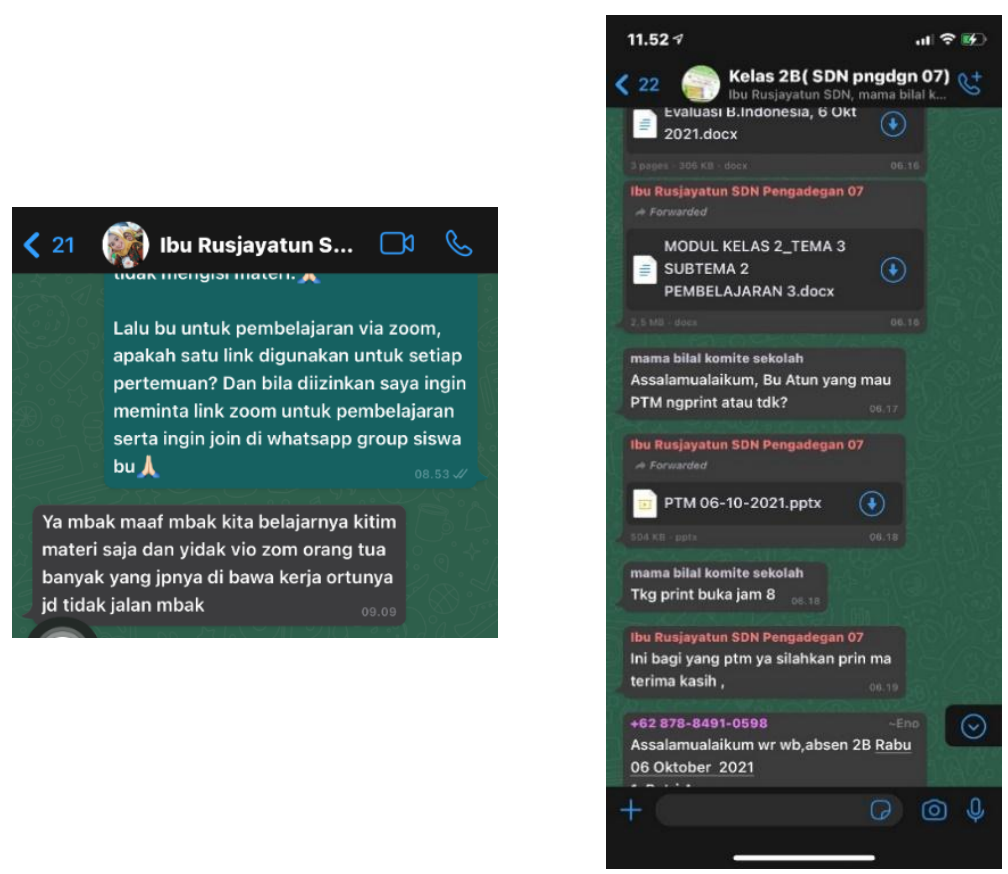

Gambar 1: Observasi dan Wawancara guru kelas 2B mengenai proses pembelajaran secara daring

2. Kendala yang Dialami Guru dan Siswa

Selama Proses Pembelajaran Daring

Kelas 2B SDN Pengadegan 07

Jakarta

a. Kendala Guru

\section{Pada}

kegiatan

pembelajaran secara daring dikelas 2B peneliti mendapatkan hasil berupa kendala yang dialami oleh guru dan siswa. Kendala yang dialami oleh guru yaitu berupa waktu kegiatan pembelajaran yang terbatas yang menyebabkan guru tidak leluasa dalam menerangkan 
dan menjelaskan materi. Selain itu guru juga tidak mengetahui mengenai pemahaman siswa tentang materi yang disampaikan oleh guru pada saat proses pembelajaran secara daring dikarenakan proses pembelajaran hanya dilakukan melalui whatsapp group sehingga guru tidak mengetahui apakah siswa benar benar memahami pembelajaran atau tidak dan apakah yang mengerjakan tugas siswa itu sendiri atau orang tua maupun anggota keluarga lain, kendala lain yang dihadapi guru yaitu berupa pengiriman tugas atau materi yang terlalu tinggi bahkan pembahasannya diluar dari materi tematik dikarenakan adanya pembuatan tugas perwilayah, selain itu, terkadang ada juga orang tua siswa yang mengirimkan tugas di malam hari dikarenakan orang tua siswa tersebut bekerja di siang hari sehingga baru bisa membantu anaknya dalam menyampaikan serta menyelesaikan materi tugas yang dikirimkan oleh gurunya, sehingga memperlambat proses koreksi dan penilaian tugas, hal ini juga ditunjang dari hasil wawancara kepada guru kelas 2B, sebagai berikut : 


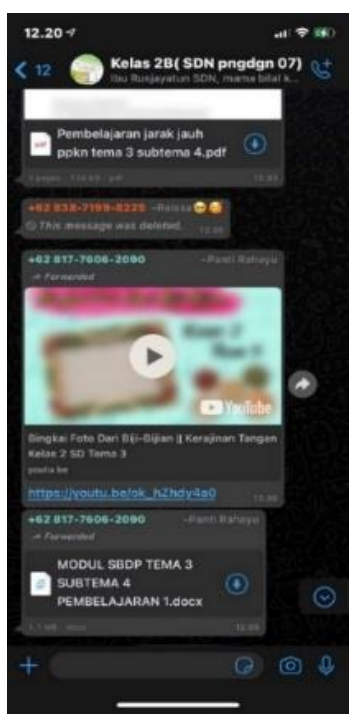

\section{Gambar 2: Observasi kendala guru terkait waktu}

Link wawancara :

https://www.youtube.com/watch?v=J7pJc1oP

$X Z s \& t=52 s$

b. Kendala Siswa

Kendala yang siswa hadapi selama kegiatan pembelajaran secara daring yaitu berupa penggunaan handphone yang hanya ada satu dan harus bergantian dengan anggota keluarga yang lain. Kemudian kendala lainnya berupa kuota yang terbatas dan cepat habis terutama jika ada pertemuan via zoom meeting serta tugas yang dikirimkan berupa video. Selain itu, siswa juga kurang memahami pembelajaran, karena tidak ada penjelasan materi secara langsung hanya pengiriman tugas dan materi via whatsapp group saja, siswa juga lebih senang ketika proses pembelajaran tatap muka dibandikan pembelajaran daring. 

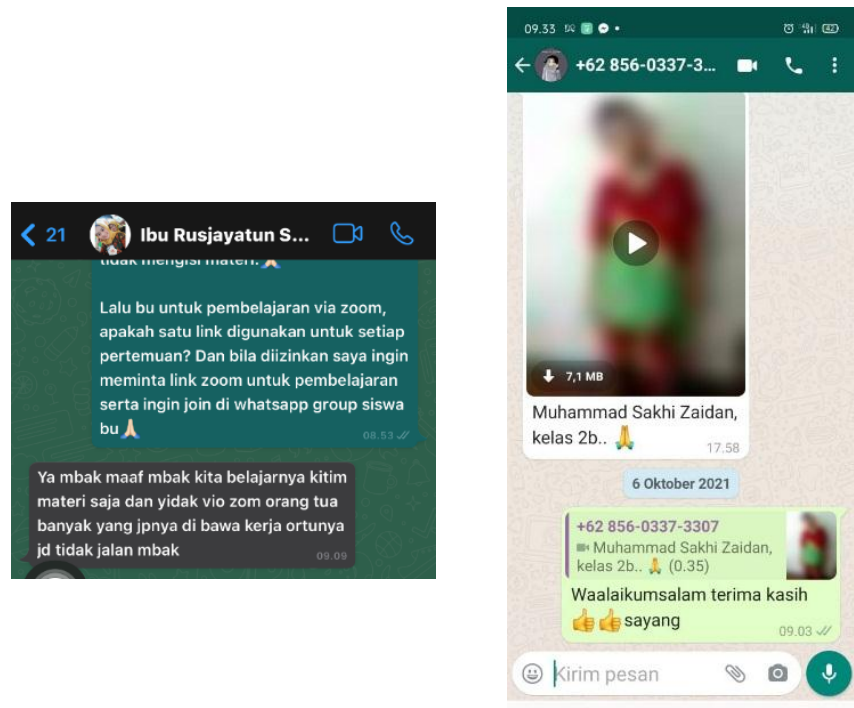

\section{Gambar 3: Wawancara guru kelas 2B mengenai kendala pengiriman dan}

\section{pengumpulan tugas siswa}

3. Upaya Guru dalam Mengatasi yang belum dipahami oleh siswa. Upaya Kendala pada Proses Pembelajaran lain yang dilakukan oleh guru yaitu Daring Kelas 2B SDN Pengadegan 07 berupa perpanjangan waktu hingga Jakarta malam hari dalam mengirimkan tugas

Upaya yang dilakukan guru untuk bagi siswa yang orang tuanya bekerja di menyelesaikan kendala pada proses siang hari. Dalam penyampaian materi pembelajaran daring yaitu guru kelas selama pembelajaran secara daring juga selalu bertanya mengenai kendala atau guru kelas berupaya untuk membuat kesulitan selama pembelajaran secara materi semenarik mungkin, misal dalam daring serta adanya waktu tambahan materi yang disampaikan tersebut disertai yang diberikan oleh guru untuk bertanya dengan gambar yang bisa menarik melalui telefon mengenai materi yang perhatian serta meningkatkan minat belum dipahami oleh siswa. Karena belajar siswa selama proses dengan adanya waktu tambahan, guru pembelajaran secara daring ini. Dalam kelas bisa menjelaskan kembali materi kegiatan proses pembelajaran daring ini 
ISSN 2548-9119

guru kelas juga melibatkan dan Pada proses pelaksanaan mengikutsertakan peran orang tua dalam pembelajaran daring dikelas 2B SDN pembelajaran tematik secara daring, guru Pengadegan 07 Jakarta, peneliti juga selalu memberikan upaya terbaik jika menemukan kendala-kendala yang siswa sedang mengalami kendala pada dialami oleh guru dan juga siswa. Berikut proses pembelajaran jarak jauh.

kendala yang dialami oleh guru yaitu berupa guru kelas 2B yang kurang

\section{Kesimpulan}

Berdasarkan hasil penelitian, pembelajaran dikelas 2B SDN Pengadegan 07 Jakarta hanya via Whatsapp Group saja tidak menggunakan Zoom meeting atau aplikasi lainnya karena dinilai kurang efektif oleh guru kelas 2B, untuk pengiriman tugas guru kelas $2 \mathrm{~B}$ hanya mengirimkan materi di Whatsapp group dan tidak ada interaksi lainnya setelah pengiriman tugas dari guru kelas 2B. Sedangkan untuk absensi kelas, siswasiswi kelas 2B mengirimkan list nama masing-masing setiap harinya dan untuk pengumpulan tugas siswa-siswi langsung mengirimkan tugasnya secara japri (jaringan pribadi) kepada guru kelas untuk dinilai. menguasai perkembangan gadget, terkadang materi tidak sesuai dengan usia siswa, waktu kegiatan pembelajaran daring juga terbatas, selain itu guru juga tidak mengetahui perkembangan pemahaman siswa tentang materi, pengiriman tugas siswa dimalam hari, guru juga tidak mengetahui siapa yang mengerjakan tugas siswa dirumah sehingga proses evaluasi hanya melalui nilai siswa-siswi kelas 2B saja. Selain kendala yang dialami oleh guru, siswa juga mengalami kendala selama proses pembelajaran daring yaitu berupa penggunaan handphone secara bergantian dengan anggota keluarga yang lainnya dan orang tua siswa yang bekerja sehingga tidak bisa mendampingi 
anaknya dalam kegiatan pembelajaran. pembelajaran daring dan adanya waktu Kemudian kendala siswa yang lain tambahan melalui telefon, guru kelas bisa berupa kuota yang terbatas dan cepat menjelaskan ulang materi yang belum habis terutama apabila adanya siswa pahami, perpanjangan waktu pertemuan melalui zoom meeting serta dalam pengiriman tugas sampai dengan tugas vidio. malam hari untuk siswa yang orang

Dari kendala yang dialami oleh tuanya bekerja, guru menyampaikan guru dan siswa terdapat upaya yang materi dengan menarik. Dalam proses dilakukan oleh guru kelas $2 \mathrm{~B}$ yaitu guru pembelajaran daring ini guru kelas $2 \mathrm{~B}$ kelas selalu bertanya mengenai kendala juga melibatkan dan mengikutsertakan dan kesulitan siswa selama proses orang tua dalam pembelajaran tematik.

\section{Daftar Pustaka}

Aditia Rigianti, H. (2020). Kendala Pembelajaran Daring Guru Sekolah Dasar. Elementary School 7 Vol 7 No 2, 6.

Anugrahana, A. (2020). Hambatan, Solusi dan Harapan: Pembelajaran Daring. Jurnal Pendidikan dan Kebudayaan, Vol. 10 No. 3, 8.

Astuti, F. (2019). Strategi Guru Kelas dalam Membentuk Karakter Peserta Didik di SDIT Permata Bunda III Bandar Lampung. Skripsi Fakultas Tarbiyah dan Keguruan Universitas Islam Negeri Raden Intan Lampung, 82.

Brawijaya, G. (2017). Analisis Evaluatif Buku Ajar Tematik Terpadu Kurikulum 2013 Kelas IV Sekolah Dasar. Skripsi Fakultas IImu Pendidikan Universitas Negeri Yogyakarta, 351.

Choirunnisa, Y. (2020). Analisis Keterampilan Mengajar Aspek Mengadakan Variasi dalam Pembelajaran Tematik Kelas IV di SDS YASPORBI I Pancoran Jakarta. Skripsi Fakultas Keguruan dan Ilmu Pendidikan Universitas Trilogi, 92.

Dewi, W. A. (2020). Dampak Covid-19 terhadap Implementasi Pembelajaran Daring di Sekolah Dasar. Jurnal Ilmu Pendidikan, 2 No. 1.

Hasibuan, Simarmata \& Sudirman, J. (2019). E-Learning: Implementasi, Strategi dan Inovasinya. Yayasan Kita Menulis. 
Helaluddin \& Wijaya. (2019). Analisis Data Kualitatif: Sebuah Tinjauan Teori \& Praktik. Sekolah Tinggi Theologia Jaffray Makasar.

Hutami, E. (2020). Kendala Pembelajaran Jarak Jauh Pada Masa Pandemi Bagi Siswa SD, Guru, dan Orangtua. 11.

Imania, K. (2019). Rancangan Pengembangan Instrumen Penilaian Pembelajaran Berbasis Daring. Jurnal PETIK. Vol 5, 47.

Kemendikbud. (2020). Keputusan Bersama Menteri Pendidikan dan Kebudayaan, Menteri Agama, Menteri Kesehatan dan Menteri Dalam Negeri Republik Indonesia. Salinan Keputusan Bersama Menteri, 42.

Kuntarto, E. (2017). Keefektifan Model Pembelajaran Daring dalam Perkuliahan. Indonesian Language Education and Literature, 110.

Mastur, M. (2020 ). Upaya Guru Dalam Melaksanakan Pembelajaran Daring Pada Masa Pandemi Covid-19 . Jurnal Pendidikan Madrasah Ibtidaiyah , 10 .

Moleong , L. (2018). Metode Penelitian Kualitatif. Bandung: PT Remaja Rosdakarya.

Nurhamidah. (2019). Upaya Meningkatkan Hasil Belajar dengan Menggunakan Model Synectics pada Pembelajaran Tematik Tema 7 Sub Tema Keragaman Suku Bangsa dan Agama di Negeriku Kelas IV MIS GUPPI 11 Rejang. Skripsi Fakultas Tarbiyah Institut Agama Islam Negeri Curup, 132.

Oknisih, W. (2019). Penggunaan Aplen (Aplikasi Online) sebagai Upaya Kemandirian Belajar Siswa. Prosiding Seminar Nasional Vol 1, 483.

Putri, I. R. (2019). Implemetasi Pendidikan Karakter pada Peserta Didik Kelas IV SD Margadana 8 Kota Tegal. Skripsi Fakultas IImu Pendidikan Universitas Negeri Semarang, 81.

Rezky, Z. A. (2020). Upaya Guru dalam Menigkatkan Aktifitas Belajar pada Pembelajaran Tematik Siswa Masa Pandemi COVID-19 Kelas V Sekolah Dasar Negeri 44/X Rantau Rasau. Skripsi Fakultas Ilmu Tarbiyah dan Keguruan Fakultas UIN Thaha Saifuddin Jambi, 100.

Rosaliza, M. (2015). Wawancara, Sebuah Interaksi Komunikasi dalam Penelitian Kualitatif . Jurnal IImu Budaya Vol 11 no 2, 9.

Salim \& Haidir. (2019). Penelitian Pendidikan: Metode, Pendekatan, dan Jenis. Depok: Kencana.

Sari, L. (2020). Upaya Menaikkan Kualitas Pendidikan dengan Pemanfaatan Youtube sebagai Media Ajar pada Masa Pandemi COVID-19. Jurnal Tawadhu Vol. 4 no. 1,11 .

Siahaan, M. (2020). Dampak Pandemi Covid-19 Terhadap Dunia. Jurnal Kajian Ilmiah (JKI) No. 1, 6.

Sugiyono. (2016). Metode Penelitian Kuantitatif, Kualitatif dan R\&D. Bandung.

121 | Analisis Kendala Proses Pembelajaran Daring di Kelas 2B SDN Pangadegan. 
Sugiyono. (2018). Metode Penelitian Kuantitatif, Kualitatif, dan R\&D. Bandung: Alfabeta.

Syah Aji, R. (2020). Dampak Covid-19 pada Pendidikan di Indonesia : Sekolah, Keterampilan, dan Proses Pembelajaran. Jurnal Sosial \& Budaya Syar-i, 10.

Taradisa, N. (2020). Kendala yang Dihadapi Guru Mengajar Daring pada Masa Pandemi COVID-19 di MIN 5 Banda Aceh. Fakultas Tarbiyah dan Keguruan. Banda Aceh. 11.

Widiasavitri, P. (2016). Bahan Ajar Mata Kuliah Psikoagnostika II (Observasi). 53.

Zainuddin Atsani, K. (2020). Transformasi Media Pembelajaran pada Masa Pandemi COVID-19. Jurnal Studi Islam Vol 1 No 1, 12. 